ISSN 1991- 8690

Website: http://jsci.utq.edu.iq

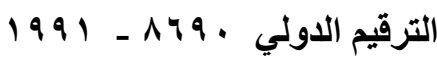

Email: utjsci@utq.edu.iq

\title{
Comparative study between the influence of processed and unprocessed semen prepared by conventional layering and centrifugation technique in infertile patients after intra-uterine insemination performance
}

\author{
Bassim KH. Kouti \\ Dheia A. A. \\ Amir H. A. \\ University of Thi-Qar
}

\begin{abstract}
$\underline{\text { Abstract }}$
This study was designed to compare the effect of prepared and unprepared semen processed by conventional layering (direct swim-up) and centrifugation swim-up technique on seminal fluid analysis parameters and pregnancy rates in infertile subjects undergoing intrauterine insemination (IUI) performance. Fifty infertile couples enrolled in this study and semen samples were analyzed before and after in vitro sperm activation by standard semen parameters. However, spermatozoa prepared by direct layering technique and centrifugation swim-up technique. Conversely, HOS-test was performed before and after in vitro sperm preparation by mixing $0.1 \mathrm{ml}$ of semen with $1.0 \mathrm{ml}$ of $150 \mathrm{mOsm} / \mathrm{L} \mathrm{NaCl}$ as a hypo-osmotic solution. Furthermore, sperm concentration, sperm motility, progressive sperm motility, normal sperm morphology, and HOS-test were evaluated according to standard WHO criteria. For IUI technique, sperm prepared and incubated for 30 minute in $5 \% \mathrm{CO}_{2}$ at $37^{\circ} \mathrm{C}$. The results of the present study indicate a highly significant $(\mathrm{P}<0.001)$ differences for all sperm functions and sperm HOS-test $(\mathrm{P}<0.001)$ were reported post in vitro sperm activation using direct swim-up and centrifugation swim-up method as compared to pre-activation. Whereas, the best results for clinical pregnancy rate were reported for semen samples prepare by using simple layering technique with IVF medium.
\end{abstract}




\section{Introduction}

The successive beginning of assisted reproduction in the human, scientists and clinicians were more and more advise to improve sperm separation techniques as the percentage of andrological cases increased rapidly (1). However, the increasing number of men showing poor semen quality encouraged the development of a wide array of different laboratory techniques focusing on the selection and enrichment of motile and functionally competent spermatozoa from ejaculate (2). The methods were developed to improve sperm functions like motility, protected sperm functions and reduced detrimental effects from environmental setting like reactive oxygen species (3). Finally, the ideal sperm separation technique should (a) be quick, easy and cost-effective, (b) isolate as much motile spermatozoa as possible, (c) not cause sperm damage or non physiological alterations of the separated sperm cells, (4) eliminate dead spermatozoa and other cells, including leukocytes and bacteria, (d) eliminate toxic or bioactive substances like decapacitation factors or reactive oxygen species (ROS), and (e) allow processing of larger volumes of ejaculates (4). An alternative complementary approach to sperm preparation for ART in vitro by means of the above discussed sperm separation methods is the idea to treat the spermatozoa in vitro in order to improve their functionality, i.e. motility, or to supply a protective environment with the purpose to maintain or improve their functional capacity for successful fertilization (5). Many substances including serum, follicular fluid or other chemically defined pharmacological substances like progesterone, adenosine analogues or methylxanthins have been proposed to stimulate human sperm functions (6).

The most important mechanisms of fertilization such as capacitation, acrosome reaction, and binding of spermatozoa to the egg surface are believed to depend on the functional integrity of the sperm membrane (7). Therefore, various tests of sperm function such as the hypo-osmotic swelling (HOS) test, and others, have been proposed for measuring male fertilization potential (8). These functions are highly affected by methods of sperm collection and preparation, composition of culture medium, sperm activation techniques (9), environmental factors (10), and other technical problems. The HOS test introduced as a clinical, physiological and non deleterious test by Jeyendran et al. (11). However, WHO (12) considered the HOS test may be used as an optional, additional and viability test. It is easy to score and give additional information on the functional integrity of sperm plasma membrane (13). The results obtained from this study indicate that semen specimens prepared by direct swim-up technique and enhanced with pentoxifylline give the best results for sperm functions test and high scores of HOS-test and successful pregnancy rate for infertile patients undergoing intrauterine insemination. In conclusion, sperm separation methods and in vitro treatments of spermatozoa is an important factor for selected successful pregnancy rates to improve their functional competence and to reduce detrimental effects after in vitro sperm activation techniques.

\section{Materials and Methods}

\subsection{Subjects}

Fifty infertile couples were enrolled in this study and semen samples were obtained from IVF Institute of Embryo Research and Infertility Treatment/Al-Nahrain University. The mean age of subjects was $31.35 \pm 0.66$ years old with range from 18-49 years and duration of infertility was $5.66 \pm 0.33$ years with range from $2-16$ years. The semen samples were collected by masturbation after 3-5 days abstinence and allow liquefying at $37^{\circ} \mathrm{C}$ in $5 \% \mathrm{CO}_{2}$ for 30 minutes and evaluated before and after in vitro sperm activation. Sperm function tests including sperm concentration, 
sperm motility, progressive sperm motility, normal sperm morphology, and HOS-test value were evaluated according to WHO criteria.

\subsection{Semen preparation and processing for IUI technique}

\subsubsection{Conventional layering technique}

The semen was prepared for IUI using $1 \mathrm{ml}$ of prepared IVF culture medium (Medi-Cult Company, Jyllinge, Denmark) was added to the test tube, and then $1 \mathrm{ml}$ of liquefied semen was layered beneath a culture medium. After incubation for 30 minute in $5 \% \mathrm{CO}_{2}$ at $37^{\circ} \mathrm{C}, 10 \mu \mathrm{l}$. of the mixture was aspirated by pasture pipette and examined under light microscope at 400X magnification for assessment parameters of sperm functions.

\subsubsection{Centrifugation swim-up technique}

One of the two portions of liquefied semen $(1 \mathrm{ml})$ was diluted and mixed gently with $(1 \mathrm{ml})$ of culture medium by a Pasteur pipette for a several times and run in a centrifuge at $2250 \mathrm{rpm}$ for 6 minute. Then after the supernatant was discarded and $1 \mathrm{ml}$ of culture medium was added to the pellet with care and again put in the incubators for 30 minute. Then, a drop (10 $\mu 1$.$) was taken and$ put on a slide and cover with a cover slip and examined at a microscope under 400X objective for assessment of sperm functions.

\subsubsection{Timing of IUI and controlled ovarian hyper-stimulation syndrome}

Sonographic examination of follicular size was starting beginning 16 day from expected menses. Intrauterine insemination (IUI) was performed by threading a very thin flexible rubber catheter through the cervix and injected washed sperm into the uterus and female were given clomiphene citrate $(50 \mathrm{mg}$ ) two times daily for 5 days (cyclic day; 2-6 day), then recombinant FSH (Gonal-F; 75IU; Serono; Italy) for another 5 days (cyclic day; 7-11). The vaginal ultrasounographic demonstration was performed for four times (7, 9, 11 and 13 day). At least, when one ovarian follicle reaches $\geq 18 \mathrm{~mm}$ average diameters associated with a serum LH of at least 200pg/ml, Human chorionic gonadotropin (hCG; 10000IU; Profasi; Serono; Rome; Italy) was injected, and later IUI was done after 36 hours and no more than 48 hours from the initiation of LH surge and 12-24 hours from the peak.

\subsubsection{Statistical analysis of the data}

Statistical analysis was performed with the SPSS version 12.00 by Statistical Package for Social Sciences Software. The data analysis was done using paired sample t-test to assess statistical differences in results of SFTs. Mean and standard error of mean (S.E.M) obtained from crude data to compare between seminal fluid analysis parameters. P-value $<0.05$ was used as a level of statistically significant.

\section{Results}

After sperm processing using IVF medium prepare with direct swim-up and centrifugation swim-up technique, sperm concentration and sperm agglutination were significantly $(\mathrm{P}<0.001)$ decreased as compared to pre-activation, while sperm motility (\%), progressive sperm motility $(\%)$, normal sperm morphology $(\%)$, and HOS-test were significantly $(\mathrm{P}<0.001)$ increased post-in vitro activation as compared to pre-activation (Table 1). The number of clinical pregnancies was $18 \%$ after in vitro sperm activation and IUI technique. As compared to centrifugation swim-up 
technique for in vitro sperm preparation and activation, the results of clinical pregnancies were significantly $(\mathrm{P}<0.05)$ increased using direct swim-up technique for in vitro sperm activation and IUI performance (Figure 1).

Table (1): In vitro sperm processing using IVF medium prepare with conventional layering and centrifugation technique in infertile patients undergoing IUI.

\begin{tabular}{|c|c|c|c|c|}
\hline \multirow{2}{*}{ Parameters } & \multicolumn{2}{|c|}{ Conventional layering technique } & \multicolumn{2}{|c|}{ Centrifugation swim-u technique } \\
\hline & Pre-activation & Post-activation & Pre-activation & Post-activation \\
\hline $\begin{array}{l}\text { Sperm Concentration } \\
\left(\times 10^{\prime} \text { spermiml }\right)\end{array}$ & $40.35 \pm 6.31$ & $22.75 \pm 3.65$ & $41.90 \pm 3.24$ & $27.55 \pm 3.12$ \\
\hline $\begin{array}{c}\text { Sperm } \\
\text { Motility }(\%)\end{array}$ & $51.00 \pm 2.55$ & $76.60 \pm 2.07$ & $54.00 \pm 2.42$ & $79.25 \pm 2.15$ \\
\hline $\begin{array}{c}\text { Progressive sperm } \\
\text { Motility }(\%)\end{array}$ & $31.90 \pm 1.66$ & $54.85 \pm 1.43$ & $37.00 \pm 1.93$ & $58.35 \pm 2.20^{a}$ \\
\hline $\begin{array}{c}\text { Sperm } \\
\text { Agglutination (\%) }\end{array}$ & $12.50 \pm 2.40$ & $0.00 \pm 0.00$ & $14.00 \pm 2.13$ & $0.00 \pm 0.00$ \\
\hline $\begin{array}{c}\text { Nomal Sperm } \\
\text { Momhology }(\%) \\
\end{array}$ & $44.50 \pm 3.20$ & $80.25 \pm 2.09$ & $49.50 \pm 2.53$ & $83.25 \pm 2.06$ \\
\hline $\begin{array}{c}\text { Sperm HOS test } \\
\text { scores }\end{array}$ & $40.50 \pm 1.64$ & $58.75 \pm 1.58^{\circ}$ & $43.05 \pm 2.52$ & $56.65 \pm 2.05^{\wedge}$ \\
\hline
\end{tabular}

Values are Mean \pm S.E.M

a: means a highly significance $(\mathrm{P}<0.001)$ different from pre-activation

No. of infertile patients $=25$ for conventional layering and 25 for centrifugation technique

Mean of age \pm S.E.M for infertile subjects prepare with conventional layering (30.05 \pm 4.87 years)

Mean of age \pm S.E.M for infertile subjects prepare with centrifugation technique $(31.75 \pm 6.10$ years $)$ 


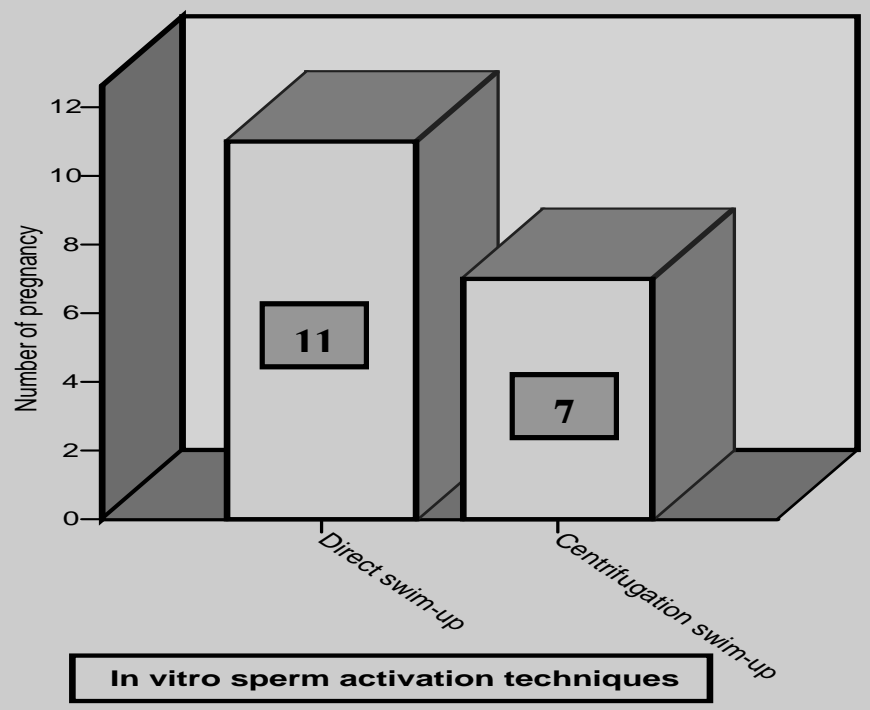

Figure (1): Outcomes of IUI for infertile couples classified according to sperm preparation techniques.

Total number of infertile subjects $=50$

No. of clinical pregnancy with direct swim-up techniques $=11$

No. of clinical pregnancy with centrifugation swim-up techniques $=7$

Mean of age for infertile men $(31.35 \pm 0.66$ years $)$

\section{Discussion}

The markedly reduction in sperm concentration and sperm agglutination was observed following in vitro sperm preparation using IVF medium and both sperm activation techniques for all infertile men undergoing IUI as compared to pre-activation. These results may be due to beneficial effect of preparation technique by removal of dead, immotile spermatozoa, and semen debris in such away only superior quality motile spermatozoa were harvested and unfortunate quality spermatozoa absent behind in the activation medium (14). Conversely, the results indicate that sperm agglutination is not specifically immune reaction; it may be due to the cytotoxic materials which secreted from the inflammatory cells which causes clumping and agglutination. In addition, sperm agglutination either specific or non specific causes sperm clustering which prevent the sperm motility and activity (15). The percentages of sperm motility, progressive sperm motility, and normal sperm morphology were significantly increased after sperm processing. Really, the enhanced sperm functions were a normal response for sperm biology after removal of seminal plasma and sperm agglutination by sperm preparation techniques (16). These parameters of spermatozoa significantly increased not only by addition of culture medium for sperm preparation as compared to unprepared semen. It was recognized that IVF medium contains protein, inorganic ions, and carbohydrates, and most necessary requirement 
for improvement sperm functions which cause an increase in the migration of normal mature active sperm to upper layer of culture medium (17).

The best improvement in sperm function and pregnancy rates was achieved by using direct swimup as compared to centrifugation swim-up techniques. Interestingly, the results of the present study are in a good agreement with results obtained by Zavos et al. (18) who reported that direct swim-up technique significantly have higher recovery of motile spermatozoa, progressive motile spermatozoa, higher DNA integrity (19), and numbers of pregnancies than centrifugation method. The selection of sperm preparation methods depend on quality of ejaculates. The ejaculates with ROS production by spermatozoa and leukocytes should not be separated by centrifugation method due to severely damage the spermatozoa (20). When semen samples prepared by centrifugation technique, functional spermatozoa can come into close cell-to-cell contact with defective sperm, leukocytes, and cell debris contained by centrifugation force causing massive oxidative damages of sperm plasma membrane via produce very high levels of ROS by pelleting of the semen with impairment of sperm functions and decrease in normally chromatin-condensed spermatozoa (21). However, the problem caused by ROS can resolve by performed directly from the liquefied semen underneath an overlay of culture medium and aspirate directly from the interface region with total number of spermatozoa recovered (22). Also, the centrifugation force adversely affects sperm motility and impairment of acrosome reaction, sperm plasma membrane, and HOS-test score in men with abnormal and normal semen analyses in comparison to density gradient centrifugation (23). Recently, the percentage of swollen spermatozoa, positive HOS-test, acrosome intact, sperm viability, and plasma membrane integrity separated by directly swim-up is significantly higher than those separated by centrifugation technique due to injurious effect of centrifugation force on sperm functions and HOS-test (24). Poor IUI outcome may be related to improper preparation techniques with release of harmful ROS as well as separation of motile and active sperm from the rest of semen can significantly improve pregnancy rates. However, the HOS-test results on sperm after direct swim-up techniques strongly correlated to IUI outcome and predict embryo cleavage (25). It was reported that common laboratory factors like centrifugation, washing, temperature fluctuation, and processing delay harmfully affect HOS response pattern of human spermatozoa both positively and negatively due to direct influence of laboratory interventions on cytoskeletal assemblies (26). The spermatozoa selected by layering technique enhanced sperm penetration results in zona free hamster egg by sperm penetration assay. Though, sperm prepared by layering technique for IUI give greatest clinical pregnancies than other preparation techniques because mono-ovulation induction plus IUI do not give better clinical results compared with mono-ovulation plus timed vaginal intercourse (27).

$\underline{\text { Zn PPM Concentration in serum }}$

\begin{tabular}{|c|c|c|c|c|c|c|c|c|c|c|c|}
\hline \multicolumn{2}{|c|}{ ControlG } & & \multicolumn{2}{|c|}{$\underline{\mathrm{H} 2 \mathrm{O} 2 \mathrm{G}}$} & \multicolumn{4}{|c|}{$\underline{\mathrm{H} 2 \mathrm{O} 2+\mathrm{Vit} \mathrm{E}}$} & \multicolumn{3}{|c|}{$\underline{\mathrm{H} 2 \mathrm{O} 2}+$ Concentrate } \\
\hline$\underline{0}$ & 21 & 42 & 0 & 21 & 42 & 0 & 21 & 42 & 0 & 21 & 42 \\
\hline 2.2 & 2.1 & 2.2 & 2.1 & 1.8 & 1.6 & 2.1 & 2.20 & 2.0 & 2.1 & 2.3 & 2.3 \\
\hline 2.1 & 2.2 & 2.4 & 2.2 & 1.5 & 1.5 & 2.3 & 1.90 & 2.1 & 2.3 & 2.2 & 2.5 \\
\hline 2.3 & 2.4 & 2.0 & 2.5 & 1.3 & 1.3 & 2.4 & 2.10 & 1.9 & 2.1 & 2.5 & 2.6 \\
\hline 2.4 & 2.0 & 2.1 & 1.9 & 1.6 & 1.4 & 2.5 & 1.98 & 2.1 & 2.0 & 2.6 & 2.1 \\
\hline 2.1 & 2.1 & 2.1 & 2.4 & 1.7 & 1.5 & 2.6 & 2.00 & 1.5 & 2.1 & 2.1 & 2.2 \\
\hline 2.1 & 2.2 & 2.1 & 2.6 & 1.8 & 1.7 & 2.1 & 1.90 & 2.2 & 2.3 & 2.4 & 2.3 \\
\hline
\end{tabular}


$\underline{\text { Mg ion PPM Concentration in serum }}$

$\underline{\mathrm{H} 2 \mathrm{O} 2 \mathrm{G}} \quad \underline{\mathrm{H} 2 \mathrm{O} 2+\mathrm{Vit} \mathrm{E}} \quad \underline{\mathrm{H} 2 \mathrm{O} 2+\text { Concentrate }}$

\begin{tabular}{llllllllllll}
0 & 21 & 42 & 0 & 21 & 42 & 0 & 21 & 42 & 0 & 21 & 42 days \\
\hline 12.05 & 12.00 & 12.1 & 12.0 & 15.2 & 15.2 & 12.1 & 13.1 & 13.30 & 12.0 & 12.9 & 14.1
\end{tabular}

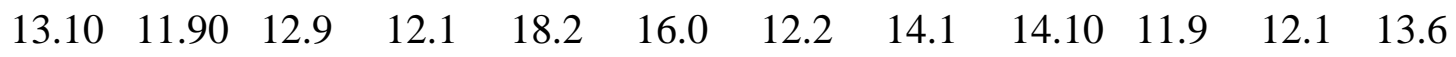

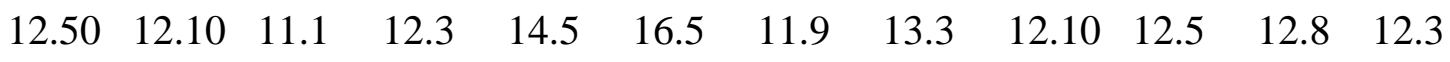

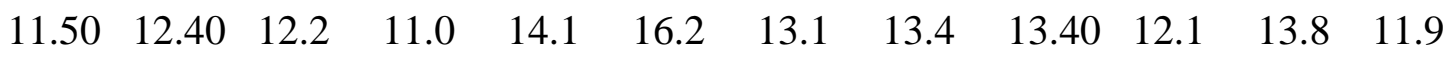

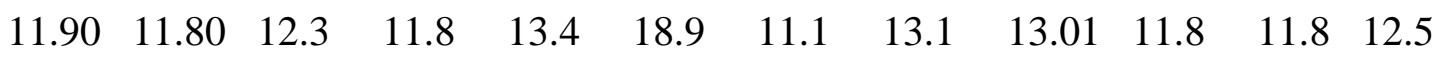

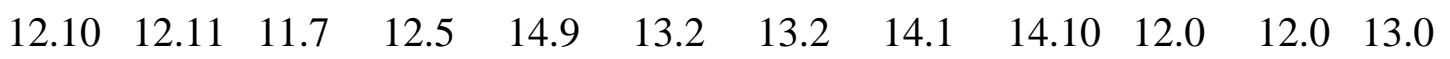

$\underline{\text { Ca ion PPM Concentration in serum }}$

$\underline{\mathrm{H} 2 \mathrm{O} 2 \mathrm{G}} \quad \underline{\mathrm{H} 2 \mathrm{O} 2+\mathrm{Vit} \mathrm{E}} \quad \underline{\mathrm{H} 2 \mathrm{O} 2+\text { Concentrate }}$

\begin{tabular}{llllllllllll}
0 & 21 & 42 & 0 & 21 & 42 & 0 & 21 & 42 & 0 & 21 & 42 days \\
\hline 127.5 & 125.3 & 126.6 & 126.4 & 123.1 & 119.5 & 126.2 & 123.4 & 124 & 126.1 & 125.5 & 126.6
\end{tabular}

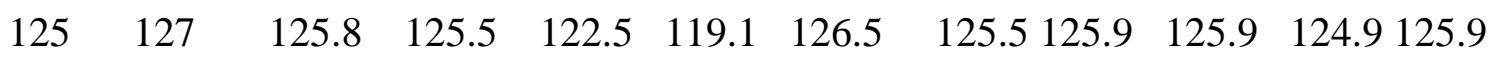

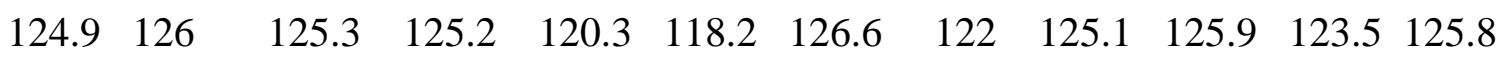

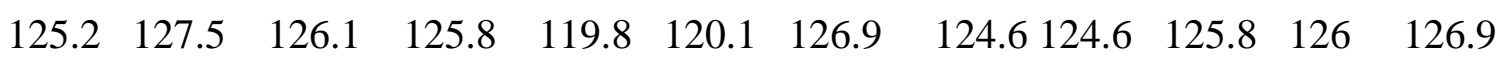

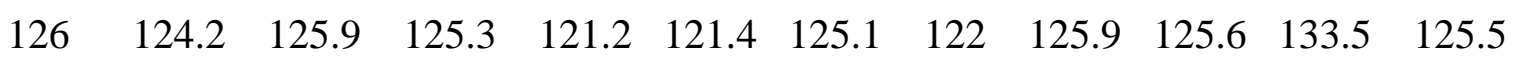

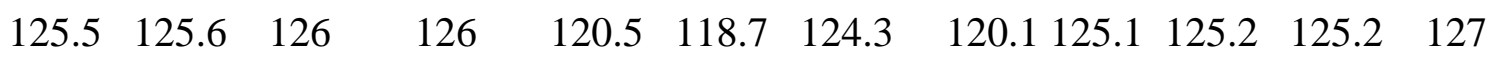


Iron PPM Concentration in serum

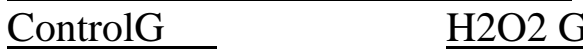

$\underline{\mathrm{H} 2 \mathrm{O} 2+\mathrm{Vit} \mathrm{E}} \quad \underline{\mathrm{H} 2 \mathrm{O} 2+\text { oncentrate }}$

\begin{tabular}{lllccccccccc}
0 & 21 & 42 & 0 & 21 & 42 & 0 & 21 & 42 & 0 & 21 & 42 days \\
\hline 10.2 & 10.1 & 10.8 & 10.1 & 7 & 6.1 & 10.1 & 8.1 & 8 & 10 & 9.5 & 11.1
\end{tabular}

$\begin{array}{llllllllllll}10.1 & 10.2 & 10.5 & 10.5 & 7.2 & 7 & 10 & 8.5 & 8.1 & 10.2 & 9.9 & 10.5\end{array}$

$\begin{array}{llllllllllll}10.15 & 10.22 & 10.6 & 10.6 & 7.8 & 7.6 & 10.4 & 8.2 & 7.9 & 10.6 & 9.3 & 9.7\end{array}$

$\begin{array}{llllllllllll}10.21 & 10.4 & 10.1 & 10.2 & 7.3 & 6.6 & 10.5 & 7.4 & 8 & 10.3 & 10.1 & 9.9\end{array}$

$\begin{array}{llllllllllll}10.16 & 10.5 & 10.3 & 10.3 & 8.1 & 6.5 & 10.3 & 7.9 & 7.3 & 10.1 & 10.5 & 11\end{array}$

$\begin{array}{llllllllllll}10.01 & 10 & 10 & 10.4 & 6.1 & 6.1 & 10.1 & 7.6 & 7.6 & 10.2 & 10.4 & 10.2\end{array}$

$\mathrm{Pb}$ PPM Concentration in serum

$\underline{\underline{\mathrm{H} 2 \mathrm{O} 2 \mathrm{G}}} \quad \underline{\mathrm{H} 2 \mathrm{O} 2+\mathrm{Vit} \mathrm{E}} \quad \underline{\mathrm{H} 2 \mathrm{O} 2+\text { Concentrate }}$

\begin{tabular}{lrrrrrrrrrrl}
0 & 21 & 42 & 0 & 21 & 42 & 0 & 21 & 42 & 0 & 21 & 42 days \\
\hline 165 & 160 & 160 & 160 & 140 & 149 & 160 & 145 & 153 & 163 & 150 & 166
\end{tabular}

$\begin{array}{llllllllllll}160 & 161 & 161 & 164 & 139 & 130 & 155 & 149 & 148 & 160 & 155 & 162\end{array}$

$\begin{array}{llllllllllll}159 & 164 & 158 & 159 & 141 & 131 & 160 & 150 & 155 & 161 & 156 & 158\end{array}$

$\begin{array}{llllllllllll}158 & 158 & 162 & 158 & 145 & 119 & 158 & 140 & 140 & 151 & 153 & 159\end{array}$

$\begin{array}{llllllllllll}155 & 159 & 165 & 157 & 141 & 129 & 160 & 139 & 145 & 159 & 159 & 165\end{array}$

$\begin{array}{llllllllllll}160 & 159 & 159 & 158 & 135 & 140 & 163 & 137 & 140 & 160 & 150 & 166\end{array}$

R.B.C Count

$\underline{\mathrm{H} 2 \mathrm{O} 2 \mathrm{G}} \quad \underline{\mathrm{H} 2 \mathrm{O} 2+\mathrm{Vit} \mathrm{E}} \quad \underline{\mathrm{H} 2 \mathrm{O} 2+\text { Concentrate }}$

\begin{tabular}{llllllllllll}
0 & 21 & 42 & 0 & 21 & 42 & 0 & 21 & 42 & 0 & 21 & 42 days \\
\hline 4.2 & 4.2 & 4.3 & 4.8 & 4 & 4.1 & 4.7 & 5.1 & 5.2 & 4.8 & 4.8 & 5.5
\end{tabular}

$\begin{array}{llllllllllll}5.11 & 5.1 & 4 & 4.1 & 3.2 & 4.3 & 4.2 & 4.8 & 4.8 & 4.1 & 4.9 & 6.5\end{array}$

$\begin{array}{llllllllllll}4.58 & 6.3 & 5.5 & 5.2 & 4.2 & 4.2 & 5.3 & 5.5 & 5.5 & 5.3 & 5.6 & 5.4\end{array}$

$\begin{array}{llllllllllll}6.12 & 4.4 & 6.2 & 6.1 & 4.1 & 4.4 & 6.1 & 6.2 & 6.5 & 6 & 6.6 & 6.5\end{array}$

$\begin{array}{llllllllllll}4.1 & 4.1 & 6.3 & 6.6 & 4.9 & 4.7 & 4.5 & 6.1 & 6.9 & 4.8 & 6.3 & 6.2\end{array}$

$\begin{array}{llllllllllll}6.2 & 6.5 & 4.8 & 4.7 & 4.8 & 4.6 & 6.8 & 6.3 & 6.5 & 6.4 & 6.7 & 5.5\end{array}$ 
$\mathrm{Hb} \mathrm{g} / \mathrm{dL}$ Concentration in serum

$\underline{\underline{\mathrm{H}} 2 \mathrm{O} 2 \mathrm{G}} \quad \underline{\mathrm{H} 2 \mathrm{O} 2+\mathrm{Vit} \mathrm{E}} \quad \underline{\mathrm{H} 2 \mathrm{O} 2+\text { Concentrate }}$

\begin{tabular}{llcccccccccc}
0 & 21 & 42 & 0 & 21 & 42 & 0 & 21 & 42 & 0 & 21 & 42 days \\
\hline 9.3 & 9.4 & 9.2 & 9.2 & 8.2 & 8.5 & 9.1 & 10 & 10.2 & 9.3 & 11.1 & 12.5
\end{tabular}

$\begin{array}{llllllllllll}9.9 & 9.9 & 10.1 & 10.1 & 8.1 & 7.3 & 10.1 & 9.5 & 11.2 & 9.9 & 11.2 & 11.9\end{array}$

$\begin{array}{llllllllllll}10.8 & 10.7 & 10.6 & 10.6 & 9.2 & 8.2 & 11.9 & 9.1 & 12 & 10.9 & 11.6 & 12\end{array}$

$\begin{array}{llllllllllll}12.8 & 12.7 & 12.6 & 12.7 & 9.9 & 9.1 & 10.6 & 8.9 & 13 & 12.9 & 12 & 12.4\end{array}$

$\begin{array}{llllllllllll}12.2 & 12.5 & 12.4 & 12.1 & 10 & 8.6 & 12.4 & 8.8 & 12.5 & 12.4 & 13.3 & 13.2\end{array}$

$\begin{array}{llllllllllll}13 & 12.8 & 12.6 & 12.9 & 10.1 & 8.7 & 12.9 & 8.6 & 13.5 & 12.9 & 13.2 & 13.6\end{array}$

$\underline{\text { P.C.V\% }}$

$\underline{\mathrm{H} 2 \mathrm{O} 2 \mathrm{G}} \quad \underline{\mathrm{H} 2 \mathrm{O} 2+\mathrm{Vit} \mathrm{E}} \quad \underline{\mathrm{H} 2 \mathrm{O} 2+\text { Concentrate }}$

\begin{tabular}{rccccccccccc}
0 & 21 & 42 & 0 & 21 & 42 & 0 & 21 & 42 & 0 & 21 & 42 days \\
\hline 26 & 27 & 29 & 26 & 19 & 18 & 26 & 22 & 24 & 28 & 22 & 30
\end{tabular}

$\begin{array}{llllllllllll}24 & 26 & 26 & 23 & 20 & 17 & 25.5 & 24 & 26 & 30 & 24 & 29\end{array}$

$\begin{array}{llllllllllll}29 & 28 & 29 & 28 & 21 & 20 & 28 & 26 & 28 & 22 & 23 & 28\end{array}$

$\begin{array}{llllllllllll}26 & 27 & 28 & 25 & 23 & 18 & 29 & 28 & 27 & 20 & 29 & 31\end{array}$

$\begin{array}{llllllllllll}27 & 25 & 28 & 26 & 18 & 22 & 26 & 21 & 25 & 28 & 28 & 32\end{array}$

$\begin{array}{llllllllllll}23 & 24 & 26 & 28 & 20 & 24 & 22 & 23 & 26 & 24 & 24 & 30\end{array}$

$\underline{\text { MCV fL Value }}$

$\underline{\mathrm{H} 2 \mathrm{O} 2 \mathrm{G}} \quad \underline{\mathrm{H} 2 \mathrm{O} 2+\mathrm{Vit} \mathrm{E}} \quad \underline{\mathrm{H} 2 \mathrm{O} 2+\text { Concentrate }}$ \begin{tabular}{llcccccccccc}
0 & 21 & 42 & 0 & 21 & 42 & 0 & 21 & 42 & 0 & 21 & 42 days \\
\hline 22.14 & 23 & 19 & 19 & 20 & 20 & 19 & 19 & 19 & 19.3 & 23.1 & 22.7
\end{tabular}

$\begin{array}{llllllllllll}19.3 & 19 & 25 & 24 & 25 & 19 & 24 & 19 & 23 & 24.1 & 22.8 & 18.3\end{array}$

$\begin{array}{llllllllllll}24 & 16 & 19 & 20 & 23 & 16 & 20 & 16 & 21.8 & 20.5 & 20.7 & 22.2\end{array}$

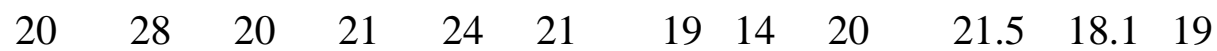

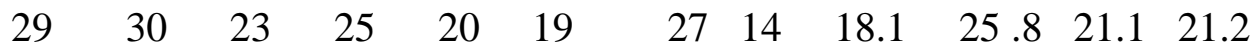

$\begin{array}{llllllllllll}20 & 19 & 26 & 19 & 21 & 18 & 18 & 13 & 20.7 & 20.1 & 19.7 & 24.7\end{array}$ 


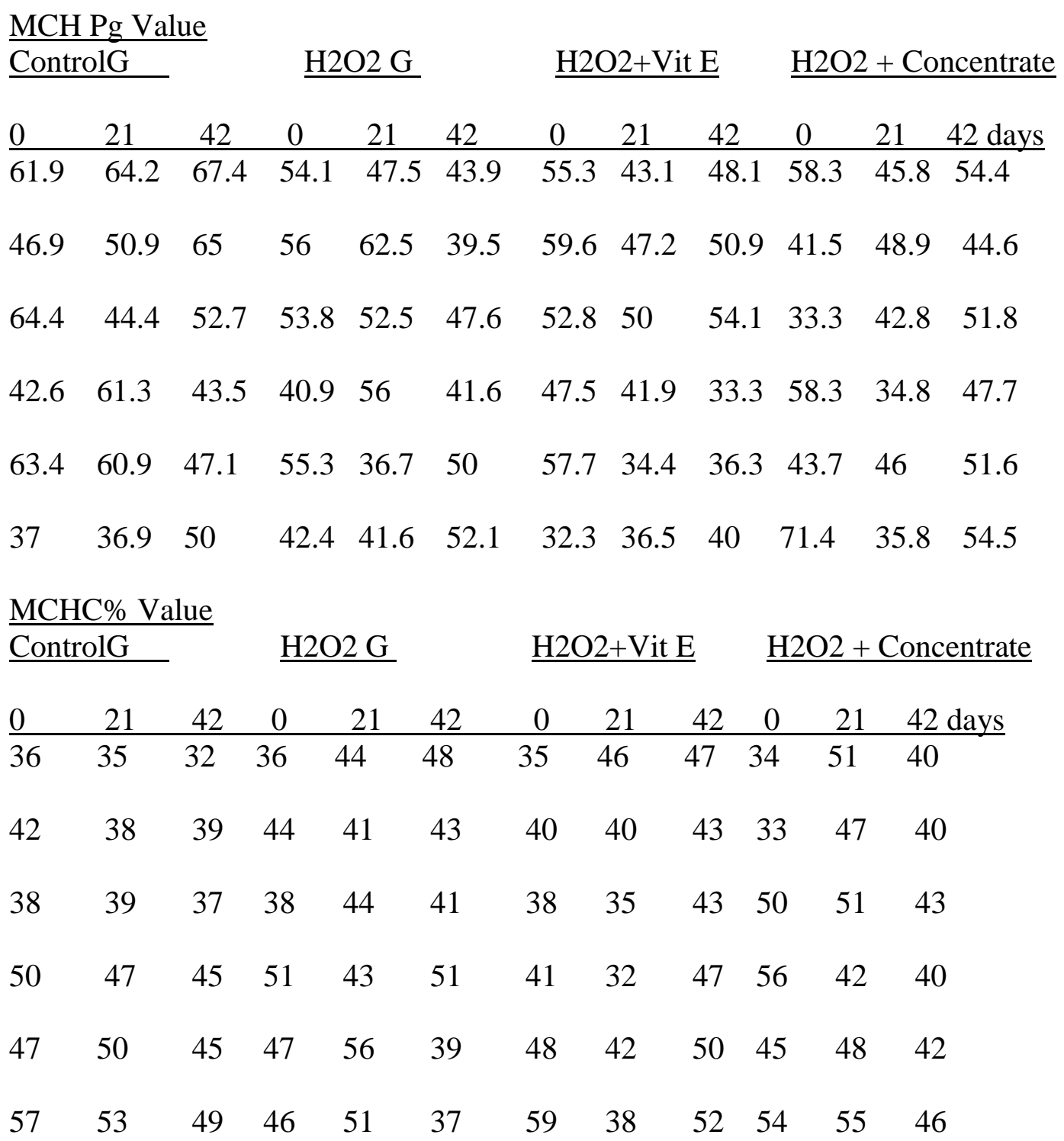

\section{$\underline{\text { References }}$}

1. Edwards RG., Steptoe PC. and Purdy JM. (1980): Establishing full term human pregnancies using cleaving embryos grown in vitro. Br. J. Obstet. Gynaecol. 87:737-756.

2. Mahadevan M. and Baker G. (1984): Assessment and preparation of semen for in vitro fertilization. In: Clinical In Vitro Fertilization Edited by: Wood C, Trounson A. Springer-Verlag, Berlin: 83-97.

3. Zavos PM., Abou-Abdallah M., Aslanis P., Correa JR. and Zarmakoupis-Zavos PN. (2000): Use of the multi-ZSC one-step standardized swim up method: recovery of high-quality spermatozoa for intrauterine insemination or other forms of assisted reproductive technologies. Fertil. Steril. 74:834-835.

4. Lopata A., Brown JB., Leeton JF., Talbot JM. and Wood C. (1978): In vitro fertilization of preovulatory oocytes and embryo transfer in infertile patients treated with clomiphene and human chorionic gonadotropin. Fertil. Steril. 30:27-35.

5. Aitken RJ. and Clarkson JS.(1988): Significance of reactive oxygen species and antioxidants in defining the efficacy of sperm preparation techniques. J. Androl. 9:367-376. 
6. Mbizvo MT., Johnson RC. and Baker GHW. (1993): The effect of the motility stimulants, caffeine, pentoxifylline, and 2-deoxyadenosine on hyperactivation of cryopreserved human sperm. Fertil. Steril. 59:1112-1117.

7. Ahmadi A. and Soon-Chye NG. (1992): The single sperm curling test. a modified hypo-osmotic swelling test, as a potential technique for the selection of viable sperm for intracytoplasmic sperm injection. Fertil. Steril. 68: 346-350.

8. Buckett WM., Luckas MJ., Aird IA., Farguharson RG., Kingsland CR. and Lewis-Jones DI. (1995): The hypo osmotic swelling test in recurrent miscarriage. Fertil. Steril. 58:506-509.

9. Mahadevan MM., Trounson AO. and Leeton JF. (1983): The relationship of tubal blockage, infertility of unknown cause suspected male infertility, and endometeriosis to success of in vitro fertilization and embryo transfer. Fertil. Steril. 40:755-762.

10. Sterzik K., Rosenbusch B., Sasse V., Wolf A., Beier HM. and Lauritzen CA. (1989): New variation of in vitro fertilization: Intravaginal culture of human oocyte and cleavage stage. Hum. Reprod. 4:84-86.

11. Jeyendran RS., Van Der Ven HH., Perez-Pelaez M., Crabo BG. and Zaneveld LJD. (1984): Development of an assay to assess the functional integrity of the human sperm membrane and its relationship to other semen characteristics. J. Reprod. Fertil. 70: 219-228.

12. World Health Organization (WHO) (1999): Laboratory Manual for the Examination of Human Semen and Semen-Cervical Mucus Interaction, 4th ed. Cambridge, Cambridge University Press UK. Pp.8-11.

13. Verheyen C., Joris H., Crits K., Nagy Z., Tournaye H. and Van Steirteghem A. (1997): Comparison of different hypo-osmotic swelling solutions to select viable immotile spermatozoa for potential use in intracytoplasmic sperm injection. Hum. Reprod. Update. 3:195-203.

14. Makkar G., Ng HY., Yeung SB. and Ho PC. (1999): Comparison of two colloidal silica-based sperm separation media with a non-silica-based medium. Fertil. Steril. 72:796-802.

15. Mahadevan MM. and Andtrounson AO. (1984): The influence of seminal characteristics on the success rate of human in vitro fertilization. Fertil. Steril. 42:400-405.

16. Liu DY. and Baker HW. (1993): Inhibition of acrosin activity with a trypsin inhibitor blocks human sperm penetration of the zona pellucida. Biol. Reprod. 48:340-8.

17. Laverage H., Desutter P. and Desmet R. (1997): Prospective randomized study comparing human serum albumin with fetal cord serum as protein supplement in culture medium for IVF-ET. Hum. Reprod.12:22636.

18. Zavos PM., Abou-Abdallah M., Aslanis P., Correa JR. and Zarmakoupis- Zavos PN. (2000): Use of the multi-ZSC one-step standardized swim up method: recovery of high-quality spermatozoa for intrauterine insemination or other forms of assisted reproductive technologies. Fertil. Steril. 74:834-835.

19. Zini A., Finelli A. and Phang D. (2000): Influence of semen processing technique on human sperm DNA integrity. Urol. 56:1081-4.

20. Sills ES., Wittkowski KM., Tucker MJ., Perloe M., Kaplan CR. and Palermo GD. (2002): Comparison of centrifugation- and non centrifugation based techniques for recovery of motile human sperm in assisted reproduction. Arch. Androl. 48:141-145.

21. Gellert-Mortimer ST., Clarke GN., Baker HWG., Hyne RV. and Johnston WIH. (1998): Evaluation of Nycodenz and Percoll density gradients for the selection of motile human spermatozoa. Fertil. Steril. 49:335-341.

22. Ord T., Patrizio P., Marello E., Balmaceda JP. and Asch RH. (1990): Mini-Percoll: A new method of semen preparation for IVF in severe male factor infertility. Hum. Reprod. 5:987-989.

23. Verberckmoes S., De Pauw I., Vanroose G., Laevens H., Van Soom A. and de Kruif A. (2000): Influence of ultracentrifugation on motility and membrane integrity of fresh sperm. Therio. 53: 490.

24. Piomboni P., Bruni E., Capitani S., Gambera L., Moretti E., La Marca A., De-Leo V. and Baccetti B. (2006): Ultrastructural and DNA Fragmentation analyses in Swim-up Selected Human Sperm. Arch. Androl. 52:51-59.

25. Evans J., Wells C., Gregory L. and Walker S. (1991): A comparison of intrauterine insemination, and natural intercourse in superovulated women. Fertil. Steril.56:1183-1187. 
26. Mackenna A. (1995): Contribution of the male factor to unexplained infertility: a review. Int. J. Androl. 1:5861.

27. Melis GB., Strigini F. and Mais V. (1990): Critical reappraisal of the clinical effectiveness of different methods of assisted fertilization. J. Endocr. Invest. 13:263-274.

ضياء عبا عودة جازع الوائلي)(r)

باسم خميس كوتي الركابي (')

عامر حسن عبد الكاظم الزبيدي(r)

\author{
(1) جامعة ذي قار- كلية العلوم - قسم علوم الحياة \\ (Y) جامعة ذي قار- قسم كلية التمريض- العلوم السريرية \\ (T) جامعة ذي قار- كلية التمريض- قدم العلوم السريرية
}

\title{
الخلاصة
}

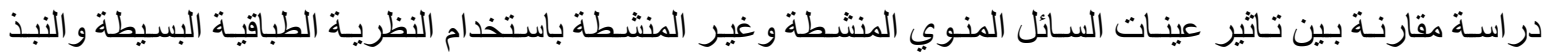

$$
\text { المركزي بعد اجر اء تقنية التلقيح الاصطناعي داخل الرحم لمرضى العقم }
$$

الخلاصـة: صممت الدر اسـة إلى مقارنـة تاثير عينـات السـائل المنوي المنشطة وغير المنشطة خـارج الجسـ باسـتخدام

النظرية الطباقية البسيطة والنبذ المركزي على متغير ات تحليل السائل المنوي ومعدلات الحمل بعد اجر اء تقنية التلقيح

الاصطناعي داخل الرحم. تضمنت الدر اسة ( • ( مريضاً) تم تقسيمهم إلى مجمو عتين ، Y مريضاً) لكل طريقة تحضير

للسائل المنوي حيث ان الرجال مصابين باسباب مختلفة للعقم و النساء خضـن إلى دورة هرمونيـة لاحداث الاباضـة، تم

جمع السائل المنوب وتقييمه قبل وبعد اجر اء عملية التنشيط خار ج الجسم.

تم تحضير عينـات السـائل المنوي بطريقة التقنيـة الطباقيـة البسيطة وطريقة النبذ المركزي باضـافة او بدون إضـافة

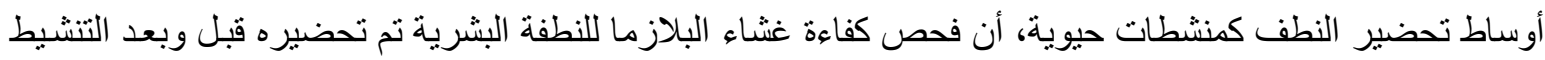

وذللك بمزج (0.1 ml) من عينة السائل المنوي مع (1.0 ml) من محلول الاختبار(HOS-test solution). أن فحوصات كفاءة النطف و التي تتضمن تركيز النطف، حركة النطف، الحركة التقدمية للنطف، النسبة المئويـة للنطف السوية تم تقييمها وفقاً الى مقررات منظمة الصحة العالمية(WHO). اظهرت النتائج فرقاً (P>0.001) معنوياً عالياً في معايير السائل المنوي وفحص كفاءة غشاء البلازما ومعدلات الحمل قبل وبعد التنشيط وبكلا طريقتي تحضبر النطف، حيث تم الحصول على افضل النتائج وذللك باستعمال النظرية الطباقية البسيطة مع وسط تحضير النطف ( Universal

.(IVF medium 